Board of Governors of the Federal Reserve System

International Finance Discussion Papers

Number 557

July 1996

\title{
FIRM SIZE AND THE IMPACT OF PROFIT-MARGIN UNCERTAINTY ON INVESTMENT: DO FINANCING CONSTRAINTS PLAY A ROLE?
}

Vivek Ghosal and Prakash Loungani

NOTE: International Finance Discussion Papers are preliminary materials circulated to stimulate discussion and critical comment. References in publications to International Finance Discussion Papers (other than an acknowledgement that the author has had access to unpublished material) should be cleared with the author or authors. 


\begin{abstract}
We study the response of investment to changes in uncertainty about future profits. We find that in industries dominated by small firms, an increase in uncertainty about future profits depresses investment; in all other industries, increased uncertainty has virtually no effect (or has a positive effect) on investment. The data set from which these findings emerge is a balanced panel, consisting of annual data from 1958 to 1991 for 252 manufacturing industries in the United States. The theoretical work on this topic points to uncertainty about future profit flows as one of the important factors that determines the ease with which firms can access external credit. The prediction made by the theory is that an increase in uncertainty exacerbates informational asymmetries, and hence makes lenders reduce the flow of credit; this in turn lowers investment in creditconstrained firms. If one is willing to accept firm size as a proxy for access to external credit, then our finding that greater uncertainty lowers investment in small-firm-dominated industries is consistent with the theoretical prediction.
\end{abstract}


Firm Size and the Impact of Profit-Margin Uncertainty on Investment:

Do Financing Constraints Play a Role?

Vivek Ghosal and Prakash Loungani*

\section{Introduction}

The results of recent research on capital market imperfections suggest that there is an important difference between the cyclical behavior of small firms and large firms. For instance, Gertler and Gilchrist (1994) find that a tightening of monetary policy affects real activity in small firms much more than in large firms. Their explanation for this finding is that firm size is a proxy for ability to access (external) capital markets. Small firms are constrained by internal funds because of informational asymmetries; many theoretical studies have shown that such asymmetries can lead to a certain class of borrowers being denied access to external capital markets.

This paper provides new evidence on the potential importance of such financing constraints in accounting for cyclical fluctuations in real activity. In particular, we study how investment responds to changes in uncertainty about future profits, and whether or not this response is different in industries that are dominated by small firms. The difference that we find is quite stark: In industries dominated by a large number of small firms, an increase in uncertainty about future profits depresses investment, but in all other industries increased uncertainty has virtually no effect (or a positive effect) on investment. The data set from which these findings emerge is a balanced panel, consisting of annual data from 1958 to 1991 for 252 SIC 4-digit U.S. manufacturing industries.

* The authors are respectively: Associate Professor in the Department of Economics, Miami University, Oxford, Ohio [e-mail: ghosalv@SBAMail.MUOhio.Edu]; and Economist in the Division of International Finance, Board of Governors of the Federal Reserve System [e-mail: lounganp@frb.gov]. This paper represents the views of the authors and should not be interpreted as reflecting those of the Board of Governors of the Federal Reserve System or other members of its staff. 
These results are of significance for a number of reasons. First, the theoretical work in this area by Stiglitz and Weiss (1981) and Gale and Hellwig (1985), among others, points to uncertainty about future profit flows as one of the key factors that determines the ease with which firms can access external credit. The prediction made by the theory is that an increase in uncertainty exacerbates informational asymmetries, and hence makes lenders reduce the flow of credit; this in turn lowers investment in credit-constrained firms. To the best of our knowledge, there is no empirical work that tests this prediction. If one is willing to accept firm size as a proxy for access to external credit, then our finding that greater uncertainty lowers investment in small-firm-dominated industries is consistent with the theoretical prediction.

Second, the particular impulse that we consider--a change in uncertainty about future profits--is very different from that considered in previous work, where the impulse considered has generally been a change in the stance of monetary policy. The fact that we find significant differences in the behavior of the two groups even in response to this impulse (uncertainty) lends support to the use of the "small vs. large firms" distinction in studies of fluctuations in economic activity.

The paper is organized as follows. Section 2 reviews the theoretical and empirical work on the link between uncertainty and credit market imperfections. Section 3 is devoted to describing two important steps that have to be taken in order to carry out our empirical tests. The first is the construction of measures of uncertainty about future profits. The second is to identify a group of industries that are dominated by small firms. An empirical model for investment is specified and estimated in Section 4. We show that the investment-uncertainty correlation is negative for the group that we identify as being dominated by small firms, but zero (or even positive) for the 'control' group (the set of all other industries). These findings are shown to be robust to: (i) alternate measures of uncertainty; (ii) alternate ways of segmenting industries into the 'small' and 'other' categories; and alternate controls for investment opportunities. Conclusions are stated in Section 5.

\section{A Review of the Literature}

\subsection{Uncertainty and Financing Constraints: Theoretical Prediction}

The idea that uncertainty affects the organization of capital markets is an old one. For instance, Hart 
(1940) describes how in the presence of uncertainty, capital markets are likely to be become "stepped" or "segmented", that is, some entrepreneurs would have rely on own funds to finance projects, whereas other entrepreneurs could fund projects via outside equity or by borrowing from middlemen such as bankers.

Stiglitz and Weiss (1981) and Greenwald, Stiglitz and Weiss (1984) revived the idea that a certain class of borrowers is likely to face financing constraints when there are informational asymmetries between borrowers and lenders. In a later extension, Greenwald and Stiglitz (1990) conduct a more direct theoretical investigation of how investment decisions are affected by equity and credit rationing at the firm level. Their model makes the following prediction (p. 19):

"Increased uncertainty about future profitability ... increases both the absolute and incremental risk of bankruptcy under quite general conditions at any level of investment and firm equity. Thus, firms respond by lowering investment since they cannot absorb the increased risks by issuing more equity."

The Greenwald-Stiglitz prediction provides the basis for the empirical tests in this paper. Like many previous tests of the 'financing constraints' theories, we test the theory by exploiting the fact that there are likely to be differences across firms in the extent to which they face financing constraints. Hence, we take the Greenwald-Stiglitz theory as predicting that the impact of increased uncertainty on investment will differ across firms. depending on the degree of access they enjoy to external capital markets.

\subsection{Firm Size and Financing Constraints}

The next step is to come up with a measure of capital market access. Following several notable studies in this area, such as Fazzari, Hubbard and Petersen (1988), Oliner and Rudebusch (1992) and Gertler and Gilchrist (1994), we use firm size as a proxy for capital market access. ${ }^{1}$ Gertler and Gilchrist (p. 313-14) argue that

1 Fazzari, Hubbard and Petersen (FHP 1988) suggest that firms with a low dividend payout ratio may be the ones that are financially constrained. However, this interpretation has been contested by Kaplan and Zingales (1995) who examine the annual reports or 10-K reports for the low-dividend firms in the FHP sample and reach the conclusion that "these firms were financially constrained in fewer than $15 \%$ of sample years." Fazzari, Hubbard and Petersen (1996) respond to this criticism and argue that the Kaplan and Zingales study is based on a flawed definition of financing constrained. 
"while size per se may not be a direct determinant, it is strongly correlated with the primitive factors that do matter. The informational frictions that add to the costs of external finance apply mainly to younger firms, firms with a high degree of idiosyncratic risk, and firms that are not collateralized. These are, on average, smaller firms."

Since our study uses industry-level rather than firm-level data, we use information on the size distribution of firms and establishments in order to segment our sample into a group of industries where small firms are dominant, and a 'control' group of other industries. We then test whether an increase in uncertainty lowers investment in the group assumed to be financially constrained, and whether or not this effect is greater than the effect in the control group.

\subsection{Investment under Uncertainty: Role of Sunk Costs}

Recent theoretical work on firms' investment behavior under uncertainty has shown that in the presence of sunk costs. where capital adjustment costs are asymmetric with downward adjustment costs being significantly greater than upward adjustment costs, an increase in uncertainty is likely to lower investment (see Dixit and Pindyck, 1994). ${ }^{2}$ From this literature it is clear that one should control for the magnitude of sunk costs when investigating any relationship between uncertainty and investment.

In the empirical work that follows we show that a negative relationship between uncertainty and investment holds only for industries dominated by a large number of small firms, and not for the relatively large firm dominated industries. Can this pattern of results be explained by differences in the extent of sunk costs across the two broad classes of industries? While a detailed examination of this issue is not undertaken here, ${ }^{3}$ we think that this is explanation for our results is unlikely. Simply put, this is because sunk costs are likely to be much lower in the small-firm dominated industries than in the large-firm dominated industries. We now spell out our line of reasoning in more detail. Industrial Organization theory has emphasized the significance of sunk costs in determining firm size and industry structure. The pioneering contribution by

\footnotetext{
${ }^{2}$ Also see Hubbard (1994) and Pindyck (1991), and the reference there.

${ }^{3}$ Primarily because there are no good measures of true sunk costs.
} 
Baumol, Willig and Panzar (1982) highlighted the role of sunk costs as a barrier-to-entry. A sunk capital cost requirement to enter into a market creates an asymmetry in the costs and risk faced by an entrant, thereby creating an entry barrier. The implication of this line of reasoning is that where sunk costs are high, industry structure is likely to be more concentrated with the presence of relatively fewer large firms--a direct consequence of entry barriers. Returning to our analysis, since we focus on industries dominated by a large number of small firms, ${ }^{4}$ it seems unlikely that in these industries sunk costs are high. Therefore, if uncertainty turns out to have an important adverse effect on investment in these small firm dominated industries, then it is more likely that the impact is due to financing constraints. ${ }^{5}$

\subsection{Empirical Work on Uncertainty and Financing Constraints}

Mackie-Mason (1988) provides evidence on the factors that influence a firm's decision on whether to obtain funding from private or public sources. One of the factors he considers is the forecast variance of a firm's earnings growth--this variable is similar in spirit to our uncertainty variable, as we describe in the next section. Mackie-Mason finds that firms with higher earnings variance "were more likely to use private sources of funds (p. 94)." His explanation for this finding is that "if a firm has volatile earnings, outsiders are more uncertain about future prospects and are less willing to buy public security issues, so such firms prefer to finance privately." However, other than this evidence on the impact of uncertainty on the choice of financing, we are not aware of a direct test of whether or not increased uncertainty has an impact on

\footnotetext{
${ }^{4}$ The data on firm size, number of firms and industry output concentration that we use are collected over a number of years and represent long-run characteristics (see Section 3.3). Further, industry structure characteristics are remarkably stable over time. For example, the correlation between the industry number of firms for the 1972 and 1982 Census years is 0.94 ; the correlation for industry four-firm output concentration ratio is 0.92 . These high correlation continue to hold across other Census years like 1963 or 1987. This timeinvariance has been documented elsewhere; see Caves and Porter (1980), Scherer and Ross (1990) and Schmalensee (1989). We stress the long-run and relative time-invariant nature of these industry characteristics as this important to the argument that our segmentation of into small and relatively large firm dominated industries is based on true structural characteristic which are not subject to much (if any) cyclical variations.

${ }^{s}$ However. as we noted earlier. this is only an indirect way of controlling for sunk costs and a proper test of the sunk cost hypothesis must wait till we have good measures of true sunk cost.
} 
investment through a tightening of financing constraints. ${ }^{6}$

\section{Data Description and Measurement of Variables}

We use the following framework for examining the impact of uncertainty on investment. First, we construct, for each industry, a time series that shows the variation in the level of uncertainty about future profits. Next, we use information provided by the Small Business Administration, as well as data on industry output concentration ratios. to partition industries into two groups: (i) industries dominated by small firms, and (ii) all other industries. Finally, we examine the effect of uncertainty on investment by pooling the data for all industries and estimating an empirical model similar to that used in many panel data studies. As a check on the robustness of our benchmark results, we present estimates for alternate measures of profit uncertainty, consider several refinements of our firm size measures, and alternate controls for investment opportunities.

\subsection{Data Sources}

With one exception (viz., the aggregate capacity utilization rate), all the data come from the Productivity Database assembled by Wayne Gray and Eric Bartlesman (1991). This data set contains annual data for SIC 4-digit industries over the period 1958-1991. The original source of the data are various issues of the Census of Manufactures and the Annual Survey of Manufactures.

Since the theory reviewed above pertained to firm-level decisions, our use of industry-level data needs to be justified. One important reason is that we wanted to obtain an uncertainty measure that contained not just cross-sectional variation but also a fair amount of time-series variation. This is crucial as we are interested in estimating the impact of changes in uncertainty on investment. The most commonly used firm-

\footnotetext{
${ }^{6}$ There is a set of recent studies that have looked at the impact of price uncertainty on investment, but these studies do not investigate the role of financing constraints. These include Caballero and Pindyck (1992), Huizinga (1993) and Ghosal and Loungani (1996.a).
} 
level data set. COMPUSTAT, offers researchers a relatively limited amount of time series variation; for instance, Gertler and Himmelberg (1993) have a sample period of 1979 to 1989, while Leahy and Whited (1996) use 1981 to 1987 as their sample. Given our chosen methodology of constructing measures of uncertainty (see Section 3.1), limited time series data poses a serious limitation. These considerations motivated the use of industry level data.

We used the following selection rules to decide which industries would be included in the sample: (i) industries classified as "not elsewhere classified" or "miscellaneous" were dropped from the sample as they do not have well defined product markets; and (ii) industries which had missing data on industry four-firm concentration ratios and firm-size were excluded in order to create a balanced panel. The imposition of these selection rules exclusions left us with 252 industries in the full sample.

\subsection{Measuring Uncertainty}

We assume that firms use a profit margin forecasting equation to predict the level of future margins. The standard deviation of the residuals from this forecasting equation is used as a measure of the degree of profit uncertainty. This notion of uncertainty is consistent with both the theoretical work ${ }^{7}$ and with previous work on the quantification of uncertainty. ${ }^{8}$

Our measure of industry profit margins is the following: $\Pi=[$ (Total Sales Revenue minus Total Variable Costs)/(Total Sales Revenue) ], where total variable costs include labor, materials and energy costs.

\footnotetext{
${ }^{7}$ See Craine (1989), Caballero (1991) and Dixit and Pindyck (1994).

${ }^{8}$ See Fisher and Hall (1969), Ghosal (1995, 1996.b), Ghosal and Loungani (1996.a), Huizinga (1993), Leahy and Whited (1996), Mackie-Mason (1990) and Winn (1977). All these studies follow the practice of using the standard deviation (or the conditional standard deviation) of some variable of interest as a measure of uncertainty.
} 
Hence, $\Pi$ is the short-run profit margin per unit of sales. ${ }^{9}$ Firms are assumed to forecast $\Pi_{t}$ and, to the extent that margins are forecastable, this reduces the uncertainty that they face. The forecasting equation is given by (1), where $\Pi_{i, t}$ is the profit margin of industry " $\mathrm{i}$ " and " $\mathrm{t}$ " is a linear trend."

$$
\Pi_{i, t}=\theta_{0}+\theta_{1} t+\theta_{2} \Pi_{i, t-1}+\theta_{3} \Pi_{i, t-2}+u_{i, t}
$$

Equation (1) controls for any deterministic trend in margins and, since we are using annual data, embeds

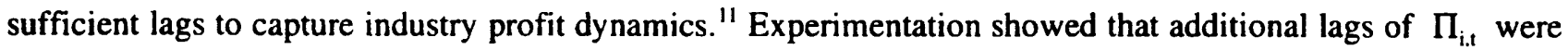
insignificant in virtually all industries.

We use the following procedure to create a time-series for the profit-margin uncertainty variable. For each industry in our sample, we estimate equation (1) using annual data over fourteen-year overlapping periods starting with 1958 ; i.e. 1958-71, 1959-72,...1977-91. The standard deviation of the residuals from these regressions is our measure of uncertainty $\sigma(\Pi)_{i, l}$, where "i" and " $t$ " index the industry and time period. Using this procedure we are able to obtain a relatively long time-series--20 observations from 1972 to 1991 --

This is a fairly commonly used measure in the industrial organization literature. See, for example, Cariton and Perloff (1994. Ch.9), Domowitz, Hubbard and Petersen (1986, 1987), Ghosal (1996.c) and Schmalensee (1989). Carlton and Perloff (p.334-343) and Schmalensee (1989) present a comprehensive discussion of various measures of profit markups, rates of return and the pitfalls associated with measuring them. Our measure $\Pi$ does not control for capital costs--which are more important for measuring true longrun profitability. In any case, as discussed by Carlton and Perloff and Schmalensee, quantifying capital costs is difficult due to problems related to valuing capital and assessing depreciation.

Our general conclusions are robust to alternate specifications of the profit equation (e.g., including an aggregate business cycle control). In Section 4.3 we present results to confirm this.

The use of autoregressive models to capture the dynamics of profit margins is quite common. See, for example, Geroski and Mueller (1990), Ghosal (1996.c) and the reference there. The basic results of the paper are not affected if we estimate the profit equation in growth rates rather than levels. 
on $\sigma(\Pi)$ for each industry. ${ }^{12}$

Next, we present summary statistics on the industry regressions run to obtain the $\sigma(\Pi)$ measure. For the first sample period--1958-71--the mean $\mathrm{R}^{2}$ (across 252 industries) of the industry regressions was 0.55 . Serial correlation was quite low, in general, with the cross-industry mean (std. dev across industries) being 0.07 (0.11). For the last 14-year period--1977-91--the mean $R^{2}$ was 0.50 . The cross-industry mean (std. dev. across industries) of the first-order serial correlation was $-0.04(0.13)$. We examined such regression characteristics for each 14-year period over which equation (1) was estimated. In general, the overall fit was quite good and serial correlation was low.

Table 1 presents some cross-industry summary statistics on $\sigma(\Pi)$ from the full sample of industries. A natural statistic for measuring the within-industry variation in $\sigma(\Pi)$ is the coefficient of variation. The numbers in the row labeled "C.V. $\sigma(\Pi)$ " show that the representative industry has a coefficient of variation of $19 \%$, with the range being from $6 \%$ to $57 \%$. Overall, there appears to be a reasonable amount of variation in $\sigma(\Pi)$ both within and across industries, which is encouraging from the viewpoint of our proposed empirical examination. Appendix A presents examples of some industries where there a lot of variation over time in the level of uncertainty, and others where there is relatively little variation over time in $\sigma(\Pi)$.

\subsection{Segmenting Industries into 'Small' versus 'Other'}

The U.S. Small Business Administration (SBA) provides a list of industries that are "dominated" by small businesses. The SBA classifies a small business as one that employs 500 workers or less. This classification was accepted by Congress in 1982 as the basis for defining a small business. An industry is

${ }^{12}$ An alternate approach would be to estimate ARCH models to construct measures of profit margin uncertainty. Our attempts to use the ARCH framework were not successful in the following sense. After imposing all the necessary restrictions for estimating ARCH models (see Hamilton, 1994, Ch. 21), we estimated second-order ARCH models for each of the 252 industries in our sample. For a very large number of industries the estimation failed to converge along with problems related to the singularity of the Jacobian. We experimented with alternate starting values as well as changing the order of the ARCH specification; none of these experiments alleviated the basic problems mentioned above. 
classified as "small business dominated" if at least $60 \%$ of industry employment is in firms with fewer than 500 employees. $^{13}$ To come up with a set of industries that are consistently dominated by small businesses, the SBA list is based on data over three different years, in particular, the 1979, 1983 and 1988 Current Population Surveys. ${ }^{14}$

It turns out that many industries on the SBA list have high four-firm concentration ratios (that is, the fraction of output accounted for by the four largest firms in the industry is high). ${ }^{15}$ Hence the fact that most firms within the industry are small--and under our hypothesis, financially constrained--can be outweighed by the fact that there are a few large firms that do not face such constrains. To mitigate the impact of this withinindustry heterogeneity, we create a sample of industries that are dominated by small businesses and have low output concentration ratios. We collected data on industry four-firm concentration ratios, CR4, from the Census of Manufactures over our sample period (to match the time period over which we have data on the uncertainty measure). For our full sample of industries, the cross-industry mean value of CR4 is approximately $40 \%$. Using this number, we define a "low" concentration industry as one that has CR $4 \leq 40 \%$ over the sample period. ${ }^{16}$ Based on this discussion, we can now define four industry groupings:

See SBA Report 1990, Tables A-24 and A-25. The SBA list of industries are typically at the SIC 3digit level of disaggregation, whereas our data are at the SIC 4-digit level. If a 3-digit industry is classified as small business dominated, we assume that all the component 4-digit industries within this 3-digit grouping are also dominated by small businesses.

Davis, Haltiwanger and Schuh (1994) show that there is considerable migration of firms across size categories; hence, to get a clear picture of industries that are truly dominated by small businesses, it is important to examine the size classification not just at a single point in time, but over a period of years. The SBA classification, based on data over a period of time. satisfies this requirement.

Some examples are Canned Seafood (SIC 2091), Roasted Coffee (SIC 2095) and Hard Surface Floor Coverings (SIC 3996), which have industry 4-firm output concentration ratios in the $55 \%$ to $90 \%$ range. The antitrust literature (see White 1987, p.16-17) tends to define a market as "non-competitive" when the concentration ratio is in the $50 \%-60 \%$ range.

A CR4 cutoff of $40 \%$ is a conservative choice because the evidence suggests that the critical CR4 beyond which industries exhibit "non-competitive" behavior appears to be in the $50 \%-60 \%$ range (see White, 1987. p.16-17; Ghosal, 1989; and the reference there). Domowitz et al. (1987, p.389) use CR4=50\% as the cutoff for low and high concentration industries. We impose the CR4 $\leq 40 \%$ cutoff over the entire sample period as some industries have a trend in CR4 and so using any one year's CR4 values 
Group 1: $\quad$ ALL industries.

Group 2: $\quad$ "SMALL business" industries (based on SBA information only).

Group 3: $\quad$ "SMALL and CR4 $\leq 40 \% "$ industries (SBA information plus concentration ratio data).

Group 4: $\quad$ all OTHER industries (based on SBA information only).

To get a better feel for the internal structure of the industries in these groupings, we examined the mean number of firms per industry over our sample period. ${ }^{17}$ For the four groups, ALL, SMALL, SMALL\&CR4 $\leq 40$ and OTHER, the mean number of firms were 695.1191, 2157 and 515, respectively. It is clear that there is a substantial difference in firm density across the SMALL and OTHER groups. Therefore, our SMALL groups are characterized by a large number of small firms, whereas the OTHER group contains a smaller number of relatively larger firms. In Tables 2 and 3 we present some summary statistics on the uncertainty measure $\sigma(\Pi)$ for the SMALL and OTHER industry groupings. As was the case for the full sample of industries, these statistics show that there is a reasonable amount of within-industry and cross-industry variation in $\sigma(\Pi)$ for both groups.

\section{Empirical Results}

\subsection{Specification}

We include our measure of uncertainty $\sigma(\Pi)_{i, t}$ in an empirical investment model for panel data. ${ }^{18}$ The dependent variable is the ratio of gross industry investment scaled by the beginning-of-period capital stock, $(\mathrm{I} / \mathrm{K})_{\mathrm{i}, \mathrm{r}}$. In addition to the uncertainty variable, current and lagged values of industry cash flow scaled by capital stock, $(\mathrm{CF} / \mathrm{K})_{\mathrm{i}, \mathrm{l}}$, are the main explanatory variables. There are two theories which motivate the

may be misleading.

${ }^{17}$ We first computed the mean number of firms for each industry over our full sample, and then computed the group mean number of firms. So the data on the number of firms is a long-run representation. Data on the number of firms were collected from various issues of the Census of Manufactures.

${ }^{18}$ For specification of panel data investment models see Devereux and Schiantarelli (1990), Fazzari, Hubbard and Petersen (1988), Fazzan and Petersen (1993) and the reference there. 
inclusion of cash flow in an investment model. The first is that cash flow (or earnings) is a signal of the future marginal productivity of capital; the second is that cash flow is a measure of internal funds, and the correlation between cash flow and investment is therefore an indication of financing constraints on investment. Sorting out which of these two theories is generating the correlation has been the focus of many previous studies; however, it is not crucial here because our tests on financial constraints are based on the impact of the uncertainty variable, rather than the cash flow variable. We did not attempt to construct a cost-of-capital measure or Tobin's "q", viriables which are suggested by alternate models of investment. ${ }^{19}$ This is because the results from previous studies do not offer much reason for preferring these measures to cash flow. Fazzari, Hubbard and Petersen (1988) show that the omission of the "q" variable or the cost-of-capital measure does not significantly affect the performance of the investment model. ${ }^{20}$

An industry-specific fixed-effect, $\alpha_{i}$, is included to capture time-invariant influences on an industry's mean level of investment over the sample period. To capture economy-wide influences on investment that are common to all industries in any given year, we include a set of year time dummies $\gamma_{r}$. This is an important control, because the time dummies can account for the influence of the myriad shocks--ranging from changes in tax rates to events such as oil price shocks--that can affect investment, but are not explicitly included in the empirical model.

Lastly, it is a stylized fact that investment spending shows persistence (see Chirinko 1993). As is standard in the empirical literature, we account for this by including a lagged dependent variable. Combining the above features, the investment model is given by equation (2). All variables in equation (2) are measured in logarithms, and so the coefficient estimates can be interpreted as elasticities.

\footnotetext{
${ }^{19}$ Furthermore, Tobin's $q$ is very difficult to construct at the industry level. We are not aware of any study that constructs industry-specific measure of Tobin's $q$.
}

Also see Chirinko (1993). See Cummins, Hassett and Hubbard (1994) for some contrasting results. 


$$
\begin{aligned}
(I / K)_{i, t}= & \alpha_{i}+\gamma_{t}+\Psi_{1} \sigma(\mathrm{II})_{i, t}+\Psi_{2}(C F / K)_{i, t} \\
& +\Psi_{3}(C F / K)_{i, t-1}+\Psi_{4}(I / K)_{i, t-1}+\omega_{i, t}
\end{aligned}
$$

We estimate equation (2) for the four industry groups described in Section 3. Based on our discussion of the theory, we expect the uncertainty elasticity $\Psi_{1}$ to be negative for Groups 2 and 3; we also expect that investment should be more responsive to uncertainty in these two groups than in Group 4. In addition to these key hypotheses of interest, the results of previous studies lead us to expect that the cash flow elasticities $\Psi_{2}$ and $\Psi_{3}$ will be positive, and larger for Groups 2 and 3 than for Group 4.

Table 4 shows the global mean (i.e. the mean over all observations in the sample) and standard deviation for the industry variables for the four groups. Other than the fact that the mean ratio of cash flow to capital is a little bit higher in the two categories of "small" firms than in the "other" categories, there is not much difference in these summary statistics across the groups.

\subsection{Main Results}

We use the fixed-effects OLS estimator to obtain estimates of the parameters in equation (2). ${ }^{21}$ Columns 1-4 of Table 5 present the results of estimating equation (2) for our four groups. The top row indicates the industry group. The numbers reported are the coefficient estimates of the $\Psi$ parameters; to save space, the estimates of the industry-fixed effects $\left(\alpha_{i}\right)$ and time-fixed effects $\left(\gamma_{t}\right)$ are not reported. Examining the results for the small business groups in columns 2 and 3, it is evident that greater uncertainty decreases investment in these industries and the elasticity estimates are significant at conventional levels. We also note that the uncertainty elasticity gets quantitatively larger when we impose the CR4 restriction (column

\footnotetext{
${ }^{21}$ Hsiao (1986) shows that inclusion of lagged dependent variables in panel data models may lead to biased estimates of the dynamic coefficients. However, Hsiao shows that this bias is likely to be a problem in panels with extremely small number of observations in the time domain. Our panel has 20 observations in the time domain and this bias is likely to be very small. Further, using a strategy that is common in the literature (e.g., Fazzari and Petersen, 1993). we verified that our basic conclusions about the impact of uncertainty are unaffected if we exclude lagged investment from the equation.
} 
3). The estimates show that the uncertainty elasticity ranges from about -0.12 to -0.16 in the small business dominated industries. Turning to the results for the OTHER industries in column 4 , we notice a sharp difference: the uncertainty elasticity is positive, relatively small $(0.06)$ and significantly different from zero.

We briefly comment on the cash flow coefficients. As in many previous studies, the estimated cash flow elasticities for the relatively financially constrained groups 2 and 3 (about 0.34 ) is greater that for Group 4 (0.27). However, the quantitative distinctions here are not very large.

Since our Group 3 definition uses information on both "size" and "concentration". we conducted a check to see whether one of the two characteristics was the dominant force behind the results on the impact of uncertainty. We created a sample of industries with $C R 4 \leq 40$ and no control for size. The coefficient estimate (std. error) on $\sigma(\Pi)$ for this group was $-0.059(0.051)$. This estimate is quantitatively much smaller than the estimate reported in Column 3 , and it is statistically insignificantly different from zero. Hence, the CR4 control by itself is not generating the observed outcome: the small business classification does play an important independent role. ${ }^{2}$

To summarize, the results thus far show that greater uncertainty decreases investment in the small business dominated industries, but not in other industries. Hence, the results support the predictions of the financing constraints theories.

\subsection{Additional Results}

In this section we present numerous additional results to check the robustness of our basic finding of a negative relationship between profit uncertainty and investment in the small business sector.

4.3(a). Durable versus Nondurable Goods Producing Industries: The excessive volatility of durable goods

In an earlier paper, Ghosal and Loungani (1996.a), examined the impact of "price" uncertainty on current investment in competitive versus oligopolistic industries. Our results indicated a negative impact of price uncertainty on investment in the relatively competitive industries. 
industries relative to nondurables is well documented. To examine whether some of our results were being driven by such intrinsic product characteristics, we partitioned our full sample of industries into durables and nondurables and reestimated the investment equation. For durable goods industries the estimated profit uncertainty elasticity (std. error) was $0.06(0.034)$; for nondurable goods industries the estimated elasticity (std. error) was $-0.01(0.035)$. Thus it does not appear that the distinction between small v. large businesses, and the result for the small business industries, that we report are being driven primarily by product durability characteristics.

4.3(b). An Alternate Measure of Uncertainty: To check the robustness of our results, we constructed an alternate measure of uncertainty by estimating equation (3). Equation (3) includes one lag of $\Pi$ and two lags of manufacturing capacity utilization rate $\mathrm{CU}$. The inclusion of $\mathrm{CU}$ is motivated by the results in Domowitz, Hubbard and Petersen $(1986,1987)$ which show that business cycle fluctuations play a key role explaining changes in industry profit margins. ${ }^{23}$ It could be argued that equation (3) may generate a superior measure of uncertainty as the forecasting equation includes additional and relevant variables in the firms' information set.

$$
\Pi_{i, t}=\beta_{0}+\beta_{1} t+\beta_{2} \Pi_{i, t-1}+\beta_{3} C U_{t-1}+\beta_{4} C U_{t-2}+v_{i, t}
$$

The standard deviation of the residuals obtained from estimating equation (3) is our second measure of uncertainty, $\sigma(\text { alt })_{\mathrm{i}, \mathrm{r}}$. We then estimate regressions similar to those reported in Table 5 for the four groups, using $\sigma($ alt $)$ in place of $\sigma(\Pi)$. The estimates of the uncertainty elasticities are presented in the Table 6. It is evident that we find the same pattern of differences in the uncertainty elasticities across the four groups that we reported earlier.

We conducted a few additional experiments to see if the estimated impact of uncertainty is sensitive

Also see Ghosal (1996.c) on this issue. 
to the specification of the profit margins equation. These include: (i) experimenting with alternate lag lengths in equations (1) and (3), (ii) estimating the profit margins equation in growth rates instead of levels, and (iii) using proxies other than CU to capture aggregate conditions. Our general conclusions do not change.

4.3(c). Refinements of the SBA Size Measure: It is well known that the size distribution of firms within an industry is often highly skewed. ${ }^{24}$ In the results reported thus far, we tried to control for this within-industry heterogeneity by conditioning on CR4; here we try a different approach, using data on the size distribution of establishments from the 1982 Census of Manufactures (CM) ${ }^{25}$ For each SIC 4-digit industry in the U.S. manufacturing sector, CM provides a complete distribution of establishment size (based on employment). Table 7 provides evidence that the size distribution of establishments may be a reasonable proxy for the size distribution of firms. An advantage of using the CM data is that we now get size classifications at the SIC 4-digit level of disaggregation as compared to the SBA 3-digit classification. A potentially important limitation is that these data are for one year and therefore present only a "snapshot" of the size distribution (in contrast to the SBA classification which is based on data over a number of years).

Our strategy is to take the SBA SMALL list (that is, our Group 2) and condition on the CM establishment size distribution data to create the following three even smaller sub-groups:

(i) SMALL(50) -- this group consists of those industries which are included in our category "Group 2: SMALL" and also satisfy the constraint that the percentage of establishments with $\leq 50$ employees is "greater than or equal to" 0.817 (the 50th percentile value). Table 8 provides percentile values for other cut-offs. Conditioning on, say, the 75 th percentile value results in very small samples.

(ii) SMALL(100) -- Industries which are included in SMALL and satisfy the constraint that the percentage of establishments with $\leq 100$ employees is greater than or equal to the 50 th percentile value.

For early work on this issue, see the classic contribution by Simon and Bonini (1958).

Note that the SBA classifications that we use are based on data over 1979-88. Therefore the 1982 Census of Manufactures roughly represents the midpoint. 
(iii) SMALL(500) -- Industries which are included in SMALL and satisfy the constraint that the percentage of establishments with $\leq 500$ employees is greater than or equal to the 50 th percentile value.

These classifications create groups of industries that are likely to be populated by even smaller firms than the SBA SMALL category. We then estimate regressions similar to those reported in Table 5 for these three new groups, using the two measures of uncertainty, $\sigma(\Pi)$ and $\sigma($ alt). Table 9 presents estimates of the profit margin uncertainty coefficients from these six regressions. While the effect is not monotonic, the estimates show that greater profit margin uncertainty continues to have a significant negative impact on current investment in all three small business dominated groups. As shown in Table 10, uncertainty continues to have virtually no (or positive) impact on current investment in industries that are in our OTHER category, even when we condition further on the CM data. This conclusion holds for both the $\sigma(\Pi)$ and $\sigma($ alt $)$ measures of uncertainty.

4.3(d). Industry Sales as the Control Variable: In all our specifications so far we have used industry cash flows $(\mathrm{CF} / \mathrm{K})$ as the primary control variable. To check whether our results are sensitive to alternate controls, we reestimated the investment equation by replacing $(\mathrm{CF} / \mathrm{K})$ with the ratio of industry sales to capital $(\mathrm{S} / \mathrm{K})$. In such an equation, firms' investment opportunities are assumed to be captured by movements in sales. Table 11 presents estimates of the uncertainty coefficients for the 4 industry groupings. The regressions contain current and one lag of $(\mathrm{S} / \mathrm{K})$, industry fixed-effects and year dummies. The results continue to support our earlier findings from Table 5. We also reestimated the investment equation with $(\mathrm{S} / \mathrm{K})$ as the control variable and used the SMALL(50), SMALL(100) and SMALL(500), and OTHER(50), OTHER(100) and OTHER(500) groups described in Tables 9 and 10. The profit uncertainty elasticities were negative and consistently statistically significant for the SMALL(.) groups, and positive and insignificant for the OTHER(.) groups. Hence, using $(\mathrm{S} / \mathrm{K})$ as the control variable preserves our conclusions regarding the adverse impact of profit margin uncertainty on current investment in small business dominated industries. 


\section{Conclusions}

Theoretical work points to uncertainty about future profit flows as one of the important factors that determines the ease with which firms can access external credit. The prediction made by the theory is that an increase in uncertainty exacerbates informational asymmetries, and hence makes lenders reduce the flow of credit; this in turn lowers investment in credit-constrained firms. This paper measures the impact of uncertainty on investment in industries dominated by small firms, and compares it with the impact in a 'control' group of other industries. Under the maintained hypothesis that firm size is a proxy for capital market access, the empirical results in this paper are consistent with the theory. We find that an increase in uncertainty about future profit margins lowers current investment in industries dominated by small businesses, but has no impact in the 'control' group.

As Ramey (1993. p. 7-8) has emphasized, even though the small-versus large-firm results seem to offer "very compelling evidence in favor of the hypothesis that there are credit market imperfections," that does not necessarily imply that such imperfections are important at the aggregate level:

"... none of the studies of firms by size classes have shown that the reaction of small firms has an aggregate impact. This is an important link in the argument because one can think of equilibrium forces that would mitigate the aggregate effect. For example, the loss in output from small firms ... might be compensated by a rise in output from large firms."

This describes the situation here, because we find that even though there is a differential impact across size classes, there is no appreciable effect of uncertainty on manufacturing investment as a whole. However, it is worth pointing out that small firms play a more important role outside the manufacturing sector than within manufacturing. Dennis (1993) estimates that "77 percent of all small businesses fall into broadly defined services. Fewer than one in ten small businesses are manufacturers." This suggests that evidence from the service sector on the impact of uncertainty on investment is needed in order to gauge whether or not uncertainty has an important impact on economy-wide investment, and a better understanding of the impact of financing constraints on small firms' investment outlays. 


\section{References}

Baumol, William, John Panzar, and Robert Willig. Contestable Markets and the Theory of Industry Structure. San Diego: Harcourt Brace Jovanovich, 1982.

Bernanke, Ben, and Mark Gertler. "Financial Fragility and Economic Performance," Quarterly Journal of Economics, 1990, 87-114.

Caballero, Ricardo. "On the sign of the investment-uncertainty relationship." American Economic Review, 81, 1991, 279-288.

Caballero, Ricardo, and Robert Pindyck. "Investment, uncertainty and industry evolution." NBER working paper \# 4160, 1992.

Caves, Richard, and Michael Porter. "The Dynamics of Changing Seller Concentration," Journal of Industrial Economics, 1980, 1-15.

Carlton, Dennis and Jeffrey Perloff. Modern Industrial Organization. New York: Harper Collins, 1994.

Chirinko, Robert and Huntley Schaller. "Why Does Liquidity Matter in Investment Equations?," Journal of Money Credit and Banking, 1995. 527-548.

Chirinko, Robert. "Business Fixed Investment Spending: A Critical Survey of Modeling Strategies, Empirical Results, and Policy Implications." Working Paper \# 93-01, Federal Reserve Bank of Kansas City, 1993.

Calomiris, Charles, and R. Glenn Hubbard. "Firm Heterogeneity, Internal Finance, and Credit Rationing," Economic Journal, 1990, 90-104.

Cummins, Jason, Kevin Hassett, and R. Glenn Hubbard, "A Reconsideration of Investment Behavior Using Tax Reforms as Natural Experiments," Brookings Papers on Economic Activity, 1994 (2), 1-75.

Craine, Roger. "Risky Business: The Allocation of Capital." Journal of Monetary Economics, 1989, 201-218.

Davis, Steven, John Haltiwanger and Scott Schuh. "Small Business and Job Creation: Dissecting the Myth and Reassessing the Facts," Business Economics, 1994, 13-21.

Dennis Jr., William. A Small Business Primer. The NFIB Foundation, 1993..

Devereux, Michael, and Fabio Schiantarelli. "Investment, Financial Factors, and Cash Flow: Evidence from U.K. Panel Data," in Hubbard, R. Glenn ed. Asymmetric Information. Corporate Finance, and Investment. Chicago: University of Chicago Press, 1990.

Dixit, Avinash, and Robert Pindyck. Investment under Uncertainty. Princeton: Princeton University Press, 1994.

Domowitz, Ian, Glenn Hubbard, and Bruce Petersen. "Business Cycles and the Relationship between Concentration and Price-Cost Margins." RAND Journal of Economics, 1986, 1-17. 
Domowitz, lan, R. Glenn Hubbard, and Bruce Petersen. "Oligopoly Supergames: Some Empirical Evidence on Prices and Margins." Journal of Industrial Economics, 1987, 379-398.

Fazzari, Steven, R. Glenn Hubbard, and Bruce Petersen. "Financing Constraints and Corporate Investment." Brookings Papers on Economic Activity, 1988, 141-195.

Fazzari, Steven, R. Glenn Hubbard, and Bruce Petersen. "Financing Constraints and Corporate Investment: Response to Kaplan and Zingales," NBER Working Paper \# 5462. 1996.

Fazzari, Steven, and Bruce Petersen. "Working capital and fixed investment: new evidence on financing constraints." RAND Journal of Economics, 1993, 328-342.

Fisher, I.N., and G.R. Hall. "Risk and Corporate Rates of Return," Quarterly Journal of Economics, 1969, 79 92.

Gale, Douglas, and Martin Hellwig. "Incentive-Compatible Contracts I: The One-Period Problem," Review of Economic Studies, 1985, 647-664.

Geroski, Paul, and Dennis Mueller. "The Persistence of Profits in Perspective," in Dennis Mueller ed., The Dynamics of Company Profits. Cambridge: Cambridge University Press, 1990.

Gertler, Mark. "Financial Structure and Aggregate Economic Activity," Journal of Money, Credit, and Banking, 1988, 559-588.

Gertler, Mark, and Simon Gilchrist. "Monetary Policy, Business Cycles, and the Behavior of Small Manufacturing Firms," Quarterly Journal of Economics, 1994, 309-340.

Ghosal. Vivek, and Prakash Loungani. "Product Market Competition and the Impact of Price Uncertainty on Investment." Journal of Industrial Economics Vol 44, 1996(a), 217-29.

Ghosal, Vivek. "Does Uncertainty Influence the Number of Firms in an Industry?" Economics Letters, 1996(b), 229-37.

Ghosal, Vivek. "Product Market Competition and Industry Price-Cost Markup Fluctuations," Working Paper, Department of Economics, Miami University, 1996(c).

Ghosal, Vivek. "Input Choices Under Uncertainty," Economic Inquiry Vol 33, 1995, 142-158.

Ghosal, Vivek. "Market Structure, Price-Cost Margins and Unionism," Economics Letters Vol 29, 1989, 179 82.

Gilchrist, Simon, and Charles Himmelberg, 1992. "Evidence on the Role of Cash Flow in Reduced Form Investment Equations," Working Paper, Board of Governors of the Federal Reserve System.

Greenwald, Bruce and Joseph Stiglitz. "Macroeconomic Models with Equity and Credit Rationing," in Hubbard, R. Glenn. ed., Asymmetric Information. Corporate Finance, and Investment. Chicago: University of Chicago Press, 1990, 15-42.

Gray, Wayne, and Eric Bartlesman. "The Productivity Data Set," National Bureau of Economic Research, 
1991

Greenwald, Bruce, Joseph Stiglitz, and Andrew Weiss. "Information Imperfections in the Capital Market and Macroeconomic Fluctuations."American Economic Review, 1984, 194-199.

Hamilton, James. Time Series Analysis. Princeton, NJ: Princeton University Press, 1994.

Hart, A.G. Anticipations. Uncertainty and Dynamic Planning. New York: A.M. Kelly, 1951.

Hsiao, Cheng. Analysis of Panel Data. Cambridge: Cambridge University Press, 1986.

Hubbard, R. Glenn. "Investment under Uncertainty: Keeping One's Options Open," Journal of Economic Literature Vol 32, 1994, 1816-1831.

Hubbard, R. Glenn. (ed.). Asymmetric Information. Corporate Finance, and Investment. Chicago: University of Chicago Press, 1990.

Huizinga. John. "Inflation uncertainty, relative price uncertainty and investment in U.S. manufacturing industries." Journal of Money, Credit, and Banking, 1993, 521-549.

Kaplan, Steven and Luigi Zingales. "Do financing constraints explain why investment is correlated with cash flow?" NBER Working Paper \# 5267, 1995.

Leahy, John, and Toni Whited. "The Effect of Uncertainty on Investment: Some Stylized Facts," Journal of Money Credit and Banking Vol 28, 1996, 64-83.

Mackie-Mason, Jeffrey. "Do Firms Care Who Provides Their Financing?" in Hubbard, Glenn. ed., Asymmetric Information. Corporate Finance, and Investment. Chicago: University of Chicago Press, 1990, 63-103.

Oliner, Stephen, and Glenn Rudebush. "The Transmission of Monetary Policy to Small and Large Firms," Working Paper, Board of Governors of the Federal Reserve System, 1992.

Pindyck, Robert. "Irreversibility, Uncertainty and Investment," Journal of Economic Literature Vol 29, 1991, $1110-1148$.

Ramey, Valerie. "How important is the credit channel in the transmission of monetary policy?" CarnegieRochester Conference Series on Public Policy, 39, 1993, 1-46.

Scherer, F., and D. Ross. Industrial Market Structure and Economic Performance. Boston: Houghton Mifflin Company.

Schmalensee, Richard. "Inter-Industry Studies of Structure and Performance," in Schmalensee, Richard and Robert Willig, eds., Handbook of Industrial Organization, Amsterdam: North Holland, 1989.

Simon, Herbert, and Charles Bonini. "The Size Distribution of Business Firms," American Economic Review 48, 1958, 607-17.

Small Business Association. The State of Small Business: A Report of the President, 1990. 
Stiglitz, Joseph, and Andrew Weiss. "Credit Rationing in Markets with Imperfect Information," American Economic Review, 1981, 393-410.

White, Lawrence. "Symposium on Mergers and Antitrust," Journal of Economic Perspectives, 1987, 13-22.

Winn, Darryl. "On the Relations between Rates of Return, Risk and Market Structure, Quarterly Journal of Economics 91, 1977, 57-63. 
Appendix A: Variation in $\sigma(\Pi)$ over Time

Table A.1: Some industries with very low variation over time in $\sigma(\Pi)$

\begin{tabular}{|c|c|}
\hline Industry (SIC) & Standard deviation of $\sigma(\Pi)$ \\
\hline Natural and processed cheese $(2022)$ & 0.0009 \\
\hline Fibre cans and drums (2655) & 0.0006 \\
\hline Book publishing (2731) & 0.0008 \\
\hline Toilet preparations $(2844)$ & 0.0013 \\
\hline Fabricated structural metal (3441) & 0.0012 \\
\hline Screw machine products $(3451)$ & 0.0012 \\
\hline Farm machinery and equipment (3523) & 0.0009 \\
\hline Ball bearings ( 3562 ) & 0.0015 \\
\hline Transformers $(3612)$ & 0.0011 \\
\hline Motors and generators $(3621)$ & 0.0008 \\
\hline \multicolumn{2}{|c|}{ Table A.2: Some industries with very high variation over time in $\sigma(\Pi)$} \\
\hline Industry (SIC) & Standard deviation of $\sigma(\Pi)$ \\
\hline Canned seafood (2091) & 0.0108 \\
\hline Roasted coffee (2095) & 0.0094 \\
\hline Tire cord and fabric (2296) & 0.0080 \\
\hline Organic fibers $(2824)$ & 0.0077 \\
\hline Gum and wood chemicals (2861) & 0.0117 \\
\hline Black carbon (2895) & 0.0087 \\
\hline Electrometallurgical products ( 3313 ) & 0.0094 \\
\hline Fabricated pipe fittings (3498) & 0.0089 \\
\hline Commercial laundry equipment (3582) & 0.0079 \\
\hline Carbon and graphite products ( 3624 ) & 0.0124 \\
\hline
\end{tabular}




\begin{tabular}{|l|l|l|l|l|}
\hline \multicolumn{5}{|c|}{$\begin{array}{c}\text { Table 1 } \\
\text { Summary Statistics on } \sigma(\Pi) \\
\text { ALL-Industries }\end{array}$} \\
\hline & Mean & Std.Dev. & Min. & Max. \\
\hline Mean $\sigma(\Pi)$ & 0.019 & 0.007 & 0.006 & 0.059 \\
\hline C.V. $\sigma(\Pi)$ & 19 & 9 & 6 & 57 \\
\hline
\end{tabular}

Notes: First we compute the mean value of $\sigma(\Pi)$ for each industry in the sample. This gives us 252 values. one for each of the 252 industries in the full sample. The row labeled "Mean $\sigma(\Pi)$ " presents the crossindustry summary statistics for this variable. For example. the lowest value of industry-specific mean $\sigma(\Pi)$ is 0.006 .

2. We first compute the coefficient of variation (percent), C.V., for each industry in the sample. The row labeled "C.V. $\sigma(\Pi)$ " presents the cross-industry summary statistics for this variable. For example, the representative industry in the full sample has a coefficient of variation of $\sigma(\Pi)$ of about $19 \%$. 
Table 2

Summary Statistics on $\sigma(\Pi)$

"SMALL" Business Industries

\begin{tabular}{|l|l|l|l|l|}
\hline & Mean & Std.Dev. & Min. & Max. \\
\hline Mean $\sigma(\Pi)$ & 0.019 & 0.006 & 0.007 & 0.034 \\
\hline C.V. $\sigma(\Pi)$ & 19 & 9 & 7 & 50 \\
\hline
\end{tabular}

Notes: See Table 1.

Table 3

Summary Statistics on $\sigma(\Pi)$

"OTHER" Industries

\begin{tabular}{|l|l|l|l|l|}
\hline & Mean & Std.Dev. & Min. & Max. \\
\hline Mean $\sigma(\Pi)$ & 0.019 & 0.008 & 0.006 & 0.059 \\
\hline C.V. $\sigma(\Pi)$ & 19 & 8 & 6 & 57 \\
\hline
\end{tabular}

Notes: See Table 1. 
Table 4

Panel Data Summary Statistics

Statistic
Group 1: ALL Industries (Panel Obs.=5040)

Mean

Std.Dev.

0.018

0.069

0.767

0.009

0.033

0.526

Group 2: SMALL (Panel Obs.=1340)

Mean

Std.Dev.

0.019

0.009

0.068

0.829

0.034

0.497

Group 3: SMALL and CR4 $\leq 40 \%$ (Panel Obs.=460)

Mean

0.015

0.070

0.872

Std.Dev.

0.006

0.029

0.579

Group 4: OTHER (Panel Obs.=3700)

Mean

Std.Dev.

0.018

0.069

0.744

0.008

0.032

0.535 


\begin{tabular}{|c|c|c|c|c|}
\hline \multicolumn{5}{|c|}{$\begin{array}{l}\text { Table } 5 \\
\text { Estimation Results } \\
\text { Dependent Variable: }(\mathrm{I} / \mathrm{K})_{\mathrm{it}}\end{array}$} \\
\hline & $\begin{array}{l}\text { GROUP 1: } \\
\text { ALL }\end{array}$ & $\begin{array}{l}\text { GROUP 2: } \\
\text { SMALL }\end{array}$ & $\begin{array}{l}\text { GROUP 3: } \\
\text { SMALL \& } \\
\text { CR } 4 \leq 40 \%\end{array}$ & $\begin{array}{c}\text { GROUP 4: } \\
\text { OTHER }\end{array}$ \\
\hline $\begin{array}{l}\sigma(\Pi)_{\text {it }} \\
\text { uncertainty } \\
\text { measure }\end{array}$ & $\begin{array}{l}0.014 \\
(0.023)\end{array}$ & $\begin{array}{l}-0.118 * * \\
(0.039)\end{array}$ & $\begin{array}{l}-0.159 * * * \\
(0.053)\end{array}$ & $\begin{array}{l}0.059 * * \\
(0.029)\end{array}$ \\
\hline $\begin{array}{l}(\mathrm{CF} / \mathrm{K})_{\mathrm{it}} \\
\text { cash-flow to } \\
\text { capital ratio }\end{array}$ & $\begin{array}{l}0.282 * * * \\
(0.031)\end{array}$ & $\begin{array}{l}0.339 * * * \\
(0.066)\end{array}$ & $\begin{array}{l}0.337 * * * \\
(0.110)\end{array}$ & $\begin{array}{l}0.269 * * * \\
(0.036)\end{array}$ \\
\hline$(\mathrm{CF} / \mathrm{K})_{\mathrm{it}-1}$ & $\begin{array}{l}0.189 * * * \\
(0.033)\end{array}$ & $\begin{array}{l}0.207^{* * *} \\
(0.069)\end{array}$ & $\begin{array}{l}0.088 \\
(0.113)\end{array}$ & $\begin{array}{l}0.181 * * * \\
(0.037)\end{array}$ \\
\hline $\begin{array}{l}(\mathrm{I} / \mathrm{K})_{\mathrm{it}-1} \\
\text { lagged dependent } \\
\text { variable }\end{array}$ & $\begin{array}{l}0.317 * * * \\
(0.013)\end{array}$ & $\begin{array}{l}0.235^{* * *} \\
(0.027)\end{array}$ & $\begin{array}{l}0.373 * * * \\
(0.043)\end{array}$ & $\begin{array}{l}0.349 * * * \\
(0.015)\end{array}$ \\
\hline Panel Obs. & 5040 & 1340 & 460 & 3700 \\
\hline \# Industries & 252 & 67 & 23 & 185 \\
\hline Adj- $R^{2}$ & 0.2368 & 0.2318 & 0.3308 & 0.2508 \\
\hline
\end{tabular}

Notes: $\quad$ All specifications are estimated with industry fixed-effects and year time-dummies.

2. All variables are measured in logarithms: therefore, the reported coefficients measure elasticities.

3. There are 20 time-series observations (1972-1991) per industry in all samples. Heteroscedasticityconsistent standard errors are in parentheses: ${ }^{* * *}, * *$ and $*$ imply statistical significance at the $1 \%$, $5 \%$ and $10 \%$ level.

4. GROUP 1 is the set of all manufacturing industries in the sample, GROUPS 2 consists of industries that are "dominated" by small businesses and GROUP 4 consists of all other industries. GROUP 3 is a subset of GROUP 2, and GROUP is a subset of GROUP 4.

Variable definitions:

$(\mathrm{I} / \mathrm{K})=$ Gross investment scaled by beginning-of-period capital stock.

$(\mathrm{CF} / \mathrm{K})=\quad$ Cash Flow scaled by beginning-of-period capital stock.

$\sigma(\Pi)=$ Uncertainty about profit margins

$\Pi=$ Profit margins, constructed as

(Total Sales Revenue - Total Variable Costs)/(Total Sales Revenue),

where total variable costs is the sum of labor, materials and energy costs. 


\begin{tabular}{|c|c|c|c|c|}
\hline \multicolumn{5}{|c|}{$\begin{array}{l}\text { Table } 6 \\
\text { Results with Alternate Measure of Uncertainty: } \sigma(\text { alt })\end{array}$} \\
\hline & $\begin{array}{l}\text { GROUP 1: } \\
\text { ALL }\end{array}$ & $\begin{array}{l}\text { GROUP 2: } \\
\text { SMALL }\end{array}$ & $\begin{array}{c}\text { GROUP } 3: \\
\text { SMALL \& } \\
\text { CR4 } \leq 40\end{array}$ & $\begin{array}{l}\text { GROUP 4: } \\
\text { OTHER }\end{array}$ \\
\hline$\sigma($ alt $)$ & $\begin{array}{c}0.001 \\
(0.018)\end{array}$ & $\begin{array}{l}-0.125 * * * \\
(0.035)\end{array}$ & $\begin{array}{l}-0.127 * * * \\
(0.044)\end{array}$ & $\begin{array}{l}0.055^{* *} \\
(0.023)\end{array}$ \\
\hline Panel Obs. & 5040 & 1340 & 460 & 3700 \\
\hline \# Industries & 252 & 678 & 23 & 185 \\
\hline Adj- $R^{2}$ & 0.2368 & 0.2331 & 0.3292 & 0.2510 \\
\hline
\end{tabular}




\begin{tabular}{|l|l|l|l|l|l|}
\hline \multicolumn{6}{|c|}{ Table 7} \\
Percentile Distribution of Number of Firms and Establishments per Industry: ALL Industries \\
\hline & $10 \%$ & $25 \%$ & $50 \%$ & $75 \%$ & $90 \%$ \\
\hline \#Establishments & 64 & 132 & 309 & 715 & 1620 \\
\hline \#Firms & 49 & 102 & 260 & 636 & 1524 \\
\hline$[$ Estb/Firm] & 1.02 & 1.06 & 1.14 & 1.34 & 1.57 \\
\hline
\end{tabular}

Note: The number of establishments per firm [Estb/Firm] is fairly close to 1 . Even at the 90th percentile value (1.57), there is rough equivalence between an establishment and a firm. Thus data on the size distribution of establishments appears to be a reasonable proxy for the size distribution of firms.

\begin{tabular}{|l|l|l|l|}
\hline \multicolumn{3}{|c|}{$\begin{array}{c}\text { Table 8 } \\
\text { Percentile Distribution of Establishments }\end{array}$} \\
\hline & $25 \%$ & $50 \%$ & $75 \%$ \\
\hline [ "Small" and "Other" refer to the size classes defined earlier ] \\
\hline Small \& $\leq 50$ Employees & 0.699 & 0.817 & 0.899 \\
\hline Small \& $\leq 500$ Employees & 0.983 & 0.903 & 0.963 \\
\hline Other \& $\leq 50$ Employees & 0.500 & 0.993 & 0.999 \\
\hline Other \& $\leq 100$ Employees & 0.645 & 0.650 & 0.782 \\
\hline Other \& $\leq 500$ Employees & 0.934 & 0.783 & 0.886 \\
\hline
\end{tabular}




\section{Table 9}

SMALL plus Conditioning on the Census Distribution of Establishments

\begin{tabular}{|l|l|l|l|}
\hline Measure of Uncertainty & SMALL(50) & SMALL(100) & SMALL(500) \\
\hline$\sigma(\Pi)$ & $\begin{array}{l}-0.093^{* *} \\
(0.047)\end{array}$ & $\begin{array}{l}-0.101^{* *} \\
(0.051)\end{array}$ & $\begin{array}{l}-0.124^{* * *} \\
(0.045)\end{array}$ \\
\hline & & & \\
\hline$\sigma($ alt $)$ & $\begin{array}{l}-0.133^{* * *} \\
(0.045)\end{array}$ & $\begin{array}{l}-0.142^{* * *} \\
(0.046)\end{array}$ & $\begin{array}{l}-0.124 * * * \\
(0.042)\end{array}$ \\
\hline Panel Obs. & 700 & 720 & 840 \\
\hline \# Industries & 35 & 36 & 42 \\
\hline
\end{tabular}

Note: Only the uncertainty coefficients are reported; the regressions include all explanatory variables shown in Table 5. See notes to Table 5.

\section{Table 10}

OTHER plus Conditioning on the Census Distribution of Establishments

\begin{tabular}{|l|l|l|l|}
\hline Measure of Uncertainty & OTHER(50) & OTHER(100) & OTHER(500) \\
\hline$\sigma(\Pi)$ & $\begin{array}{l}0.058^{*} \\
(0.040)\end{array}$ & $\begin{array}{l}0.045 \\
(0.040)\end{array}$ & $\begin{array}{l}0.077^{* *} \\
(0.043)\end{array}$ \\
\hline$\sigma($ alt $)$ & & & \\
\hline Panel Obs. & $\begin{array}{l}0.057^{* *} \\
(0.033)\end{array}$ & $\begin{array}{l}0.044^{*} \\
(0.029)\end{array}$ & $\begin{array}{l}0.072^{* *} \\
(0.032)\end{array}$ \\
\hline \# Industries & 1900 & 1780 & 1660 \\
\hline
\end{tabular}

\section{Notes:}

1. Only the uncertainty coefficients are reported; the regressions include all explanatory variables shown in Table 5. Also see notes to Table 5.

2. From our "OTHER" group we define three sub-groups: (i) OTHER and the percentage of establishments with $\leq 50$ employees is "less than or equal to" 0.650 (the 50 th percentile value). We denote this group as "OTHER(50)". Similarly, (ii) OTHER(100) and (iii) OTHER(500). These segmentations create industries that are populated by relatively larger firms than the "OTHER" group. 


\begin{tabular}{|c|c|c|c|c|}
\hline \multicolumn{5}{|c|}{$\begin{array}{l}\text { Table } 11 \\
\text { Sales-to-Capital Ratio, (S/K), as the Control Variable }\end{array}$} \\
\hline $\begin{array}{l}\text { Measure of } \\
\text { uncertainty }\end{array}$ & $\begin{array}{l}\text { GROUP 1: } \\
\text { ALL }\end{array}$ & $\begin{array}{l}\text { GROUP 2: } \\
\text { SMALL }\end{array}$ & $\begin{array}{l}\text { GROUP 3: } \\
\text { SMALL \& } \\
\text { CR4 } \leq 40 \%\end{array}$ & $\begin{array}{l}\text { GROUP 4: } \\
\text { OTHER }\end{array}$ \\
\hline$\sigma(\Pi)$ & $\begin{array}{l}0.024 \\
(0.023)\end{array}$ & $\begin{array}{l}-0.087^{* *} \\
(0.038)\end{array}$ & $\begin{array}{l}-0.154 * * * \\
(0.053)\end{array}$ & $\begin{array}{l}0.061 * * \\
(0.029)\end{array}$ \\
\hline$\sigma($ alt $)$ & $\begin{array}{l}0.021 \\
(0.018)\end{array}$ & $\begin{array}{l}-0.096 * * * \\
(0.033)\end{array}$ & $\begin{array}{l}-0.114 * * * \\
(0.042)\end{array}$ & $\begin{array}{l}0.059 * * * \\
(0.023)\end{array}$ \\
\hline Panel Obs. & 5040 & 1340 & 460 & 3700 \\
\hline \# Industries & 252 & 67 & 23 & 185 \\
\hline
\end{tabular}

Note: Only the uncertainty coefficients are reported. The regressions contain year-time dummies, industryfixed effects and lagged investment (as in Table 5). The Cash-flow variables are replaced by current and one-lag of industry sales-to-capital ratio. 